University of Nebraska - Lincoln

DigitalCommons@University of Nebraska - Lincoln

USDA Forest Service / UNL Faculty Publications U.S. Department of Agriculture: Forest Service -National Agroforestry Center

April 1996

\title{
INFLUENCE OF A MYCORRHIZAL FUNGUS AND/OR RHIZOBIUM ON GROWTH AND BIOMASS PARTITIONING OF SUBTERRANEAN CLOVER EXPOSED TO OZONE
}

\author{
Joseph E. Miller \\ USDA-ARS Air Quality Program \\ Steven R. Shafer \\ USDA-ARS Air Quality Program \\ Michele M. Schoeneberger \\ University of Nebraska - Lincoln, mschoeneberger1@unl.edu \\ Walter A. Pursley \\ North Carolina State University, Raleigh, NC \\ Stephanie J. Horton \\ North Carolina State University, Raleigh, NC \\ See next page for additional authors \\ Follow this and additional works at: https://digitalcommons.unl.edu/usdafsfacpub \\ Part of the Forest Sciences Commons
}

Miller, Joseph E.; Shafer, Steven R.; Schoeneberger, Michele M.; Pursley, Walter A.; Horton, Stephanie J.; and Davy, Charles B., "INFLUENCE OF A MYCORRHIZAL FUNGUS AND/OR RHIZOBIUM ON GROWTH AND BIOMASS PARTITIONING OF SUBTERRANEAN CLOVER EXPOSED TO OZONE" (1996). USDA Forest Service / UNL Faculty Publications. 27. https://digitalcommons.unl.edu/usdafsfacpub/27

This Article is brought to you for free and open access by the U.S. Department of Agriculture: Forest Service -National Agroforestry Center at DigitalCommons@University of Nebraska - Lincoln. It has been accepted for inclusion in USDA Forest Service / UNL Faculty Publications by an authorized administrator of DigitalCommons@University of Nebraska - Lincoln. 


\section{Authors}

Joseph E. Miller, Steven R. Shafer, Michele M. Schoeneberger, Walter A. Pursley, Stephanie J. Horton, and Charles B. Davy 


\title{
INFLUENCE OF A MYCORRHIZAL FUNGUS AND/OR RHIZOBIUM ON GROWTH AND BIOMASS PARTITIONING OF SUBTERRANEAN CLOVER EXPOSED TO OZONE*
}

\author{
JOSEPH E. MILLER, STEVEN R. SHAFER, MICHELE M. SCHOENEBERGER, \\ WALTER A. PURSLEY, STEPHANIE J. HORTON and CHARLES B. DAVEY \\ Research Plant Physiologist, USDA-ARS Air Quality Program, Department of Crop Science; \\ Research Plant Pathologist, USDA-ARS Air Quality Program, Department of Plant Pathology; Soil \\ Scientist, USDA-FS, Univ. of Nebraska, Lincoln, NE 68583; Research Assistant, Department of \\ Crop Science; Research Assistant, Department of Plant Pathology; and Carl Alwin Schenck \\ Professor, Department of Forestry; North Carolina State University, Raleigh, NC 27695, U.S.A.
}

(Received 19 June, 1995; accepted 29 April, 1996)

\begin{abstract}
The influence of soilborne symbionts such as rhizobia or mycorrhizal fungi on plant response to ozone $\left(\mathrm{O}_{3}\right)$ has not been well defined. Leguminous plants in the field are infected by both types of organisms, which influence plant nutrition and growth. We studied the effects of infection with Rhizobium leguminosarum biovar trifolii and/or Gigaspora margarita on response of subterranean clover (Trifolium subterraneum L. cv Mt. Barker) to $\mathrm{O}_{3}$. Exposures were conducted in greenhouse CSTR chambers using four $\mathrm{O}_{3}$ concentrations [charcoal-filtered (CF), 50, 100, or $150 \mathrm{ppb} ; 6 \mathrm{~h} \mathrm{day}^{-1}, 5$ day wk ${ }^{-1}$ for 12 weeks] as main plots (replicated). Four inoculum types were subplot treatments, i.e., inoculated with one, both, or neither microorganisms. At 2-wk intervals, plants were exposed to ${ }^{14} \mathrm{CO}_{2}$ and harvested $24 \mathrm{~h}$ later for determination of biomass and ${ }^{14} \mathrm{C}$ content of shoots and roots. Ozone at 100 or $150 \mathrm{ppb}$ suppressed clover growth during the experiment. Inoculation with $G$. margarita alone suppressed clover growth by the last two harvests, whereas $R$. leguminosarum alone enhanced growth during this time period. When both symbionts were present, the plants grew similarly to the noninoculated controls. Shoot/root ratios were increased by 100 or $150 \mathrm{ppb} \mathrm{O}_{3}$ compared to that for CF-treated plants. Shoot/root ratios were greater for all inoculated plants compared to noninoculated controls. Under low $\mathrm{O}_{3}$ stress ( $\mathrm{CF}$ or $50 \mathrm{ppb}$ ), plants inoculated with both $R$. leguminosarum and G. margarita transported a greater proportion of recent photosynthate $\left({ }^{14} \mathrm{C}\right)$ to roots than did noninoculated plants; we attribute this to metabolic requirements of the microorganisms. At the highest level of $\mathrm{O}_{3}$ stress $(150 \mathrm{ppb})$, this did not occur, probably because little photosynthate was available and the shoots retained most of it for repair of injury. Statistically significant interactions occurred between $\mathrm{O}_{3}$ and inoculum types for shoot and total biomass. When averaged across harvests, $50 \mathrm{ppb} \mathrm{O}_{3}$ suppressed biomass in the plants inoculated with G. margarita alone. Apparently, the mycorrhizal fungus is such a significant $\mathrm{C}$ drain that even a small amount of $\mathrm{O}_{3}$ stress suppresses plant growth under these conditions.
\end{abstract}

Key words: rhizobia, VAM

* Cooperative investigations of the USDA-ARS and the North Carolina State University. The research reported in this publication was funded in part by the North Carolina Agricultural Research Service and by Special Grant Number 89-34171-4499 from the Cooperative States Research Service, U.S. Dept. of Agriculture. The use of trade names in this publication does not imply endorsement by the North Carolina Agricultural Research Service or the USDA of the products named, nor criticism of similar ones not mentioned. The U.S. Government right to retain a non-exclusive, royalty-free in and to any copyright is acknowledged. 


\section{Introduction}

The photochemical air pollutant ozone $\left(\mathrm{O}_{3}\right)$ affects physiological function and growth of plants (Alscher and Wellburn, 1994), including limitation of photosynthesis and alteration of carbon (C) allocation and biomass partitioning (Miller, 1988). Reduced allocation of $\mathrm{C}$ to roots by $\mathrm{O}_{3}$ typically suppresses root growth. Interference with $\mathrm{C}$ assimilation and allocation to roots may cause indirect as well as direct effects on shoot growth.

Optimum growth of leguminous plants is usually dependent on symbiotic relations with mycorrhizal fungi and nitrogen $\left(\mathrm{N}_{2}\right)$-fixing bacteria. Mycorrhizal infection of plant roots usually stimulates plant growth through effects on nutrient uptake (especially P) and/or water supply (e.g. Safir, 1994). Under some conditions, however, mycorrhizal fungi may suppress plant growth if the benefits do not offset the sink effect on root C (Bethlenfalvay et al., 1982; Modjo and Hendrix, 1986; Safir, 1994). In most cases, infection by Rhizobium spp. provides a benefit to growth of leguminous plants unless $\mathrm{N}$ is abundant. Because the response of plants to these organisms is dependent in part on the health and $\mathrm{C}$ budget of the roots, $\mathrm{O}_{3}$ may affect plant growth indirectly by limiting $\mathrm{C}$ availability to microbial symbionts.

Ozone can suppress nodulation and $\mathrm{N}_{2}$ fixation in leguminous plants (e.g. Tingey and Blum, 1973; Montes et al., 1983; Flagler et al., 1987). Similarly, mycorrhizal infection can be suppressed by $\mathrm{O}_{3}$. For example, treatment of tomato (Lycopersicon esculentum Mill. 'Heinz 1350') plants with $300 \mathrm{ppb} \mathrm{O}_{3}$ ( $3 \mathrm{~h}$, once a wk for 9 wk) suppressed infection by Glomus fasciculatus as much as 63\% (McCool and Menge, 1983). In this case, $\mathrm{O}_{3}$ suppressed dry weight of mycorrhizal but not of non-mycorrhizal plants. Ozone (150 ppb for $6 \mathrm{~h} \mathrm{day}^{-1}, 5 \mathrm{day} \mathrm{wk}^{-1}$ for $8 \mathrm{wks}$ ) suppressed the proportion of plant $\mathrm{N}$ fixed from the air by a tripartite association of Trifolium subterraneum, Gigaspora margarita, and Rhizobium leguminosarum (Shafer and Schoeneberger, 1991b).

In most studies of $\mathrm{O}_{3}$ effects on plant growth, the presence of Rhizobium or mycorrhizal fungi has not been a controlled variable, and few experiments have addressed $\mathrm{O}_{3} \times$ symbiont interactions. In greenhouse experiments, mycorrhizal tomato plants were more sensitive than non-mycorrhizal plants to $\mathrm{O}_{3}(\mathrm{McCool}$ and Menge, 1983 and 1984). Similarly, root dry weight of Rhizobium-infected subterranean clover grown and exposed to $\mathrm{O}_{3}$ in a greenhouse was suppressed more than roots of non-infected plants (Shafer and Schoeneberger, 1991a). In a field experiment with soybean, however, mycorrhizal plants were less sensitive to $\mathrm{O}_{3}$ than non-mycorrhizal plants (Brewer and Heagle, 1983). Thus, reliable generalizations about $\mathrm{O}_{3} \times$ symbiont interactions are unavailable.

The objective of our study was to determine the separate and combined effects of a mycorrhizal fungus and Rhizobium on plant response to $\mathrm{O}_{3}$. Growth, partitioning of biomass between shoots and roots, and allocation of recent photosynthate to shoots and roots were quantified. 


\section{Methods}

Congaree loam soil (fine-loamy, mixed nonacid, thermic, Typic Udifluvents; 0$10 \mathrm{~cm}$ depth; $\mathrm{pH} 5.8,0.11 \% \mathrm{~N}, 12.0 \mathrm{mg}$ extractable $\mathrm{P} / \mathrm{kg}$ soil) was collected from the Schenck Forest in Raleigh, North Carolina, sieved (6-mm mesh), and steamed $\left(4 \mathrm{~h}\right.$ at $80{ }^{\circ} \mathrm{C}$ on three consecutive days) to eliminate indigenous rhizobia and mycorrhizal fungi. Soil was spread on a greenhouse bench and air-dried, then placed in paper bags and dried for $48 \mathrm{~h}$ at $70^{\circ} \mathrm{C}$. Polyethylene pots (11.4-cm-diam) with drain holes covered by fiberglass screen were filled with soil, and each was placed inside another pot of the same size. Seven planting holes approximately $5 \mathrm{~mm}$ diam $\times 5 \mathrm{~mm}$ deep were made in the surface of the soil in each pot. The soil was not fertilized.

Seeds of subterranean clover (Trifolium subterraneum L 'Mt. Barker') were surface-disinfested in $80 \%$ ethanol for $10 \mathrm{~min}$, rinsed five times in sterile deionized water, soaked in sterile water for $30 \mathrm{~min}$, rinsed, and placed on sterile moist filter paper in foil-covered Petri dishes for $24 \mathrm{~h}$. One seedling with a 1-2 mm-long radicle was transplanted into each of the seven holes in the soil in each pot.

Rhizobium leguminosarum biovar trifolii isolate R039 (obtained from A. G. Wollum, Dept. of Soil Science, North Carolina State University, Raleigh, NC USA) was grown at room temperature in yeast-extract-mannitol broth (YEM; Vincent, 1970) cultures on a wrist-action shaker for 4 days. Half the cultures were bulked for live inoculum, and the others were autoclaved $\left(20 \mathrm{~min}\right.$ at $\left.121^{\circ} \mathrm{C}\right)$ and bulked for Rhizobium controls. Inoculum ( $1.5 \mathrm{ml}$ per pot) was pipetted onto the seedling in each planting hole. Spores of the mycorrhizal fungus Gigaspora margarita Becker and Hall recovered from roots and soil from pot cultures with Bahaia grass (obtained from R. Roncadori, University of Georgia, Athens, GA) were surfacedisinfested in $10 \%$ chlorine bleach for $2 \mathrm{~min}$, rinsed on a sieve under running tap water for $5 \mathrm{~min}$, and diluted to 85 spores $\mathrm{mL}^{-1}$ in sterile dilute water agar $(1 \mathrm{~g}$ agar $\mathrm{L}^{-1}$ water). Control inoculum for mycorrhizal fungi was sterile water agar. Inoculum ( $2 \mathrm{~mL}$ per pot) was pipetted onto the seedling in each planting hole. The soil was then closed over the seedlings.

Plants were maintained on a bench in a nonshaded greenhouse cooled by passing charcoal-filtered air through evaporative pads. Soil was moistened several times daily with a fine mist of deionized water. Fourteen days after planting, plants were thinned to three per pot. Eighteen days after planting, the soil surface in each pot was covered by a $1.5-\mathrm{cm}$-deep layer of autoclaved perlite to insulate the soil from heat and provide some protection against soil splash.

The treatment design was a factorial combination of $\mathrm{O}_{3}$ concentrations, rhizobial inocula, and fungal inocula. Four $\mathrm{O}_{3}$ concentrations [charcoal-filtered air (CF, $<10 \mathrm{ppb} \mathrm{O}_{3}$ ), and $\mathrm{CF}$ air to which $\mathrm{O}_{3}$ was added to obtain 50, 100, or $150 \mathrm{ppb}$ ] were main-plot treatments in a replicated split-plot experimental design. Main plots were continuous-stirred tank reactor (CSTR) chambers (Heck et al., 1978) in a nonshaded greenhouse (one CSTR per $\mathrm{O}_{3}$ concentration in each of two randomized 
complete blocks). The subplot treatments were four inoculum types, i.e. inoculated with R. leguminosarum, G. margarita, both microorganisms, or neither (controls). Initially, 12 pots of each inoculum type were placed in each chamber. Plants were exposed to $\mathrm{O}_{3}$ beginning 24 days after planting and during the subsequent $12 \mathrm{wk}$ for $6 \mathrm{~h} \mathrm{day}^{-1}$ (0900-1500 h EST), 5 day wk ${ }^{-1}$ (Monday through Friday). Ozone was produced from oxygen with a corona discharge ozonator (Griffin Technics Corp., Lodi, NJ USA) and monitored by ultraviolet absorbance (Thermoelectron model 49, Thermal Electron Instruments, Hopkinton, MA). Temperatures within the CSTRs were monitored with thermocouples and averaged 21 to $22{ }^{\circ} \mathrm{C}$ for the 12-wk exposure period (average daily high 24 to $26^{\circ} \mathrm{C}$ and average daily low 19 to $20^{\circ} \mathrm{C}$ ).

Plants were labeled with ${ }^{14} \mathrm{C}$ and harvested at 2-wk intervals (six harvests) starting at 16 days after initiating $\mathrm{O}_{3}$ treatments. Plants were labeled with ${ }^{14} \mathrm{C}$ by placing two pots of each inoculum type (selected randomly) from each chamber in a plexiglass cuvette and introducing $0.01 \mathrm{mCi}$ of ${ }^{14} \mathrm{CO}_{2}$ (generated from $\mathrm{Na}_{2} \mathrm{CO}_{3}$ ) for $15 \mathrm{~min}$. Plants were labeled on two successive days (one block per day) between 1000 and $1200 \mathrm{~h} \mathrm{EST}$. After ${ }^{14} \mathrm{C}$ labeling, each pot was returned to its respective CSTR. After $24 \mathrm{~h}$, the plants were harvested in the order in which they were labeled. Plants were divided into roots and shoots. The roots were washed thoroughly, and all tissues were dried rapidly at $80^{\circ} \mathrm{C}$. Plant tissues were ground to a fine powder, and 50-mg samples in Harvey Carbon-14 Cocktail (Ox-161) were combusted to $\mathrm{CO}_{2}$ with an R.J. Harvey Biological Material Oxidizer (Model OX-200). Samples were counted with a Packard Tri-Carb Scintillation Counter.

Data were tested for homogeneity of variance, and transformations were made as directed by results of the Box-Cox test [shoot dry wt. (inverse square root); root dry wt., total dry weight, shoot/root dry wt. ratio (natural log)] (Box and Cox, 1964). Analysis was performed by GLM (SAS, 1988) with $\mathrm{O}_{3}$ as the main-plot treatment. Sums-of-squares for $\mathrm{O}_{3}$ and harvest were partitioned into single-degreeof-freedom (1df) components by orthogonal polynomial equations. Replicates (R, $=$ blocks) and $\mathrm{O}_{3}$ were tested against the $\mathrm{R} \times \mathrm{O}_{3}$ term (error a). All other effects and interactions were tested against the error $b$ term. Three pre-planned 1-df contrasts (non-inoculated vs. dual-inoculated, G. margarita only-inoculated vs. dualinoculated, and $R$. leguminosarum only-inoculated vs. dual-inoculated) were used to test inoculum effects.

The statistical model was built sequentially, starting with the full model, which included all possible polynomials. The sequence of entry of the polynomial interaction terms in the model was based on the degree (order) of the polynomial, which is defined as the sum of the powers of the components in the interaction terms (Rawlings, 1988). The lower-degree terms were entered first. The inoculum (INOC) effect was not partitioned into 1-df contrasts during model building because the three 1-df contrasts of interest had been identified in the experimental design. When all possible polynomial contrasts were included in the model, the error $b$ term was the sum of the sums of squares associated with the effects $R \times$ 
INOC, $\mathrm{R} \times \mathrm{O}_{3} \times \mathrm{INOC}, \mathrm{R} \times \mathrm{HARV}, \mathrm{R} \times \mathrm{O}_{3} \times \mathrm{HARV}, \mathrm{R} \times \mathrm{INOC} \times \mathrm{HARV}$, and $\mathrm{R} \times \mathrm{O}_{3} \times \mathrm{INOC} \times \mathrm{HARV}$, with $92 \mathrm{df}$, for which HARV=number of weeks elapsed from the onset of exposures to $\mathrm{O}_{3}$ until harvest.

The model was reduced by eliminating nonsignificant higher-order terms from the model one at a time, starting with the highest-order interaction. Sums of squares and associated degrees of freedom for nonsignificant higher-order effects were pooled with those for the error $b$ term. The regression analysis was re-run each time a term was eliminated, and the sums of squares associated with the next highest-order term were tested against the new error term. If nonsignificant, that effect was also pooled with the error term and the process was repeated. All lowerorder terms that were components of significant higher-order terms were retained in the model. The simplest model that fit all biomass variables was selected (Table I). The error term used to test the biomass variables (error $b$ ) is the sum of the sums of squares for: $\mathrm{R} \times \mathrm{INOC}, \mathrm{R} \times \mathrm{O}_{3} \times \mathrm{INOC}, \mathrm{O}_{Q} \times \mathrm{INOC}, \mathrm{O}_{C} \times \mathrm{INOC}, \mathrm{R} \times \mathrm{HARV}$, $\mathrm{R} \times \mathrm{O}_{3} \times \mathrm{HARV}, \mathrm{O}_{L} \times \mathrm{H}_{W}, \mathrm{O}_{Q} \times \mathrm{H}_{F}, \mathrm{O}_{C} \times \mathrm{H}_{C}, \mathrm{O}_{Q} \times \mathrm{H}_{W}, \mathrm{O}_{C} \times \mathrm{H}_{F}, \mathrm{O}_{C} \times$ $\mathrm{H}_{W}, \mathrm{R} \times \mathrm{HARV} \times \mathrm{INOC}, \mathrm{H}_{C} \times \mathrm{INOC}, \mathrm{H}_{F} \times \mathrm{INOC}, \mathrm{H}_{W} \times \mathrm{INOC}, \mathrm{R} \times \mathrm{O}_{3} \times$ $\mathrm{HARV} \times \mathrm{INOC}, \mathrm{O}_{Q} \times \mathrm{H}_{L} \times \mathrm{INOC}, \mathrm{O}_{L} \times \mathrm{H}_{C} \times \mathrm{INOC}, \mathrm{O}_{Q} \times \mathrm{H}_{Q} \times \mathrm{INOC}, \mathrm{O}_{C}$ $\times \mathrm{H}_{L} \times \mathrm{INOC}, \mathrm{O}_{L} \times \mathrm{H}_{F} \times \mathrm{INOC}, \mathrm{O}_{Q} \times \mathrm{H}_{C} \times \mathrm{INOC}, \mathrm{O}_{C} \times \mathrm{H}_{Q} \times \mathrm{INOC}, \mathrm{O}_{L} \times$ $\mathrm{H}_{W} \times \mathrm{INOC}, \mathrm{O}_{Q} \times \mathrm{H}_{F} \times \mathrm{INOC}, \mathrm{O}_{C} \times \mathrm{H}_{C} \times \mathrm{INOC}, \mathrm{O}_{Q} \times \mathrm{H}_{W} \times \mathrm{INOC}, \mathrm{O}_{C} \times$ $\mathrm{H}_{F} \times \mathrm{INOC}, \mathrm{O}_{C} \times \mathrm{H}_{W} \times \mathrm{INOC}$, with $152 \mathrm{df}$, for which subscripts L, Q, C, F, and $\mathrm{W}$ denote linear, quadratic, cubic, quartic, and lack-of-fit polynomial components, respectively, of sum of squares for $\mathrm{O}_{3}$ or HARV.

The model-building procedure was repeated for the proportion of ${ }^{14} \mathrm{C}$ in shoots, which was measured at harvests $2-6$, and a slightly different model was obtained. Error $\mathrm{b}$ for the final model for the proportion of ${ }^{14} \mathrm{C}$ in shoots contained the sums of squares for: $\mathrm{R} \times \mathrm{INOC}, \mathrm{R} \times \mathrm{O}_{3} \times \mathrm{INOC}, \mathrm{O}_{Q} \times \mathrm{INOC}, \mathrm{O}_{C} \times \mathrm{INOC}, \mathrm{R} \times$ HARV, $\mathrm{R} \times \mathrm{O}_{3} \times \mathrm{HARV}, \mathrm{O}_{C} \times \mathrm{H}_{C}, \mathrm{O}_{C} \times \mathrm{H}_{Q}, \mathrm{O}_{Q} \times \mathrm{H}_{F}, \mathrm{O}_{C} \times \mathrm{H}_{C}, \mathrm{O}_{C} \times \mathrm{H}_{F}$, $\mathrm{R} \times \mathrm{HARV} \times \mathrm{INOC}, \mathrm{H}_{Q} \times \mathrm{INOC}, \mathrm{H}_{C} \times \mathrm{INOC}, \mathrm{H}_{F} \times \mathrm{INOC}, \mathrm{R} \times \mathrm{O}_{3} \times \mathrm{HARV}$ $\times$ INOC, $\mathrm{O}_{L} \times \mathrm{H}_{L} \times \mathrm{INOC}, \mathrm{O}_{L} \times \mathrm{H}_{Q} \times \mathrm{INOC}, \mathrm{O}_{Q} \times \mathrm{H}_{L} \times \mathrm{INOC}, \mathrm{O}_{L} \times \mathrm{H}_{C}$ $\times$ INOC, $\mathrm{O}_{Q} \times \mathrm{H}_{Q} \times \mathrm{INOC}, \mathrm{O}_{C} \times \mathrm{H}_{L} \times \mathrm{INOC}, \mathrm{O}_{L} \times \mathrm{H}_{F} \times \mathrm{INOC}, \mathrm{O}_{Q} \times \mathrm{H}_{C}$ $\times$ INOC, $\mathrm{O}_{C} \times \mathrm{H}_{Q} \times \mathrm{INOC}, \mathrm{O}_{Q} \times \mathrm{H}_{F} \times \mathrm{INOC}, \mathrm{O}_{C} \times \mathrm{H}_{C} \times \mathrm{INOC}, \mathrm{O}_{C} \times \mathrm{H}_{F}$ $\times$ INOC, with $132 \mathrm{df}$ (Table I).

\section{Results and Discussion}

Biomass. Statistical analyses (Table I) demonstrated that main effects of $\mathrm{O}_{3}$, inoculum, and harvest were significant for shoot, root, and total biomass. Two-way and three-way interactions of $\mathrm{O}_{3}$ with harvest and/or inoculum occurred, however; thus, generalizations about main effects must be interpreted with respect to these interactions.

Ozone at 100 or $150 \mathrm{ppb}$ suppressed shoot, root, and total clover biomass over the course of the experiment, especially by the later harvests $\left(\mathrm{O}_{l} \times \mathrm{H}_{l}, \mathrm{p}<0.01\right.$; 
Table I

Mean squares for treatment effects on biomass, shoot/root ratio, and C-14 allocation in subterranean clover $^{\mathrm{a}}$

\begin{tabular}{|c|c|c|c|c|c|c|c|}
\hline \multirow[t]{3}{*}{ Source of variation } & \multicolumn{4}{|c|}{ Biomass } & \multirow{3}{*}{$\begin{array}{l}\text { Shoot/root } \\
\text { Ratio }\end{array}$} & \multirow{2}{*}{\multicolumn{2}{|c|}{$\begin{array}{l}\text { Proportion of } \\
\text { C-14 in shoot }\end{array}$}} \\
\hline & \multirow[b]{2}{*}{$\mathrm{df}$} & \multirow{2}{*}{$\begin{array}{l}\text { Shoot dry } \\
\text { Wt. (g) }\end{array}$} & \multirow{2}{*}{$\begin{array}{l}\text { Root dry } \\
\text { Wt. (g) }\end{array}$} & \multirow{2}{*}{$\begin{array}{l}\text { Total dry } \\
\text { Wt. (g) }\end{array}$} & & & \\
\hline & & & & & & $\mathrm{df}$ & C-14 \\
\hline Rep & 1 & $0.782 * *$ & $1.837 *$ & $1.936^{* *}$ & 0.005 & 1 & $0.033 *$ \\
\hline \multicolumn{8}{|l|}{ Ozone $(\mathrm{O})$} \\
\hline $\mathrm{O}$ linear $(\mathrm{OL})$ & 1 & $1.883 * *$ & $11.442 * *$ & $7.357 * *$ & $1.227^{*}$ & 1 & $0.097 *$ \\
\hline O quadratic $(\mathrm{OQ})$ & 1 & $0.094 *$ & $1.172 *$ & $0.509^{*}$ & 0.377 & 1 & $0.033^{*}$ \\
\hline $\mathrm{O}$ cubic $(\mathrm{OC})$ & 1 & $0.061 *$ & 0.152 & $0.169^{*}$ & 0.001 & 1 & 0.001 \\
\hline $\operatorname{Rep} \times \mathrm{O}(\text { error } \mathrm{a})^{\mathrm{b}}$ & 3 & 0.005 & 0.064 & 0.015 & 0.051 & 3 & 0.003 \\
\hline Inoculum (INOC) ${ }^{\mathrm{c}}$ & 3 & $0.131 * *$ & $0.457 * *$ & $0.430 * *$ & $0.139 * *$ & 3 & 0.002 \\
\hline C vs D & 1 & $0.024 *$ & $0.545^{*}$ & $0.164 *$ & $0.329 *$ & 1 & 0.003 \\
\hline D vs $R$ & 1 & $0.097 *$ & $0.448^{*}$ & $0.379 *$ & 0.008 & 1 & 0.005 \\
\hline D vs $G$ & 1 & $0.083^{*}$ & 0.047 & $0.189 *$ & $0.145^{*}$ & 1 & 0.001 \\
\hline $\mathrm{OL} \times \mathrm{INOC}$ & 3 & $0.026 * *$ & 0.039 & $0.033 *$ & 0.028 & 3 & $0.005^{*}$ \\
\hline $\mathrm{OL} \times \mathrm{C}$ vs $\mathrm{D}$ & 1 & 0.008 & 0.011 & 0.004 & $0.080 *$ & 1 & $0.012 * *$ \\
\hline $\mathrm{OL} \times \mathrm{D}$ vs $\mathrm{R}$ & 1 & 0.001 & 0.006 & 0.001 & 0.037 & 1 & 0.005 \\
\hline $\mathrm{OL} \times \mathrm{D}$ vs $\mathrm{G}$ & 1 & $0.064 *$ & 0.041 & $0.079 *$ & 0.019 & 1 & 0.001 \\
\hline Harvest Linear (HL) & 1 & $20.922 * *$ & $67.70 * *$ & $55.88 * *$ & $1.805^{* *}$ & 1 & $0.021 * *$ \\
\hline Harvest Quadratic (HQ) & 1 & $2.584 * *$ & $2.75^{* *}$ & $2.827^{* *}$ & 0.000 & 1 & 0.001 \\
\hline Harvest Cubic (HC) & 1 & 0.008 & $0.20 * *$ & $0.096^{* *}$ & 0.040 & 1 & 0.001 \\
\hline Harvest Quartic (HF) & 1 & 0.000 & 0.030 & 0.005 & 0.030 & 1 & 0.001 \\
\hline Harvest Lack-of-Fit (HW) & 1 & $0.036^{* *}$ & $0.11^{*}$ & 0.003 & $0.440 * *$ & & \\
\hline $\mathrm{OL} \times \mathrm{HL}$ & 1 & $0.040 * *$ & $0.220 * *$ & $0.429 * *$ & $0.077 *$ & 1 & 0.000 \\
\hline $\mathrm{OL} \times \mathrm{HQ}$ & 1 & 0.004 & 0.030 & 0.025 & 0.001 & 1 & 0.002 \\
\hline $\mathrm{OQ} \times \mathrm{HL}$ & 1 & 0.004 & 0.040 & 0.034 & 0.007 & 1 & 0.000 \\
\hline $\mathrm{OL} \times \mathrm{HC}$ & 1 & 0.005 & 0.020 & 0.000 & 0.032 & 1 & 0.000 \\
\hline $\mathrm{OQ} \times \mathrm{HQ}$ & 1 & 0.002 & 0.004 & 0.010 & 0.003 & 1 & 0.005 \\
\hline $\mathrm{OC} \times \mathrm{HL}$ & 1 & $0.022 *$ & 0.002 & 0.004 & 0.023 & 1 & 0.005 \\
\hline $\mathrm{OL} \times \mathrm{HF}$ & 1 & 0.002 & 0.001 & 0.003 & 0.004 & 1 & $0.010^{*}$ \\
\hline $\mathrm{OQ} \times \mathrm{HC}$ & 1 & 0.004 & 0.009 & 0.017 & 0.003 & & \\
\hline $\mathrm{OC} \times \mathrm{HQ}$ & 1 & $0.023 *$ & 0.040 & $0.067^{* *}$ & 0.017 & & \\
\hline $\mathrm{HL} \times \mathrm{INOC}$ & 3 & $0.181 * *$ & $0.546^{* *}$ & $0.567 * *$ & 0.005 & 3 & $0.013 * *$ \\
\hline $\mathrm{HL} \times \mathrm{C}$ vs $\mathrm{D}$ & 1 & $0.049 *$ & 0.033 & $0.053 *$ & 0.008 & 1 & $0.036^{* *}$ \\
\hline$H L \times D$ vs $R$ & 1 & 0.008 & 0.166 & $0.131 *$ & 0.003 & 1 & $0.015^{* *}$ \\
\hline $\mathrm{HL} \times \mathrm{D}$ vs $\mathrm{G}$ & 1 & $0.341^{*}$ & 0.716 & $0.816^{*}$ & 0.012 & 1 & 0.003 \\
\hline
\end{tabular}


Table I

Continued.

\begin{tabular}{|c|c|c|c|c|c|c|c|}
\hline \multirow[t]{3}{*}{ Source of variation } & \multicolumn{4}{|c|}{ Biomass } & \multirow{3}{*}{$\begin{array}{l}\text { Shoot/root } \\
\text { Ratio }\end{array}$} & \multirow{2}{*}{\multicolumn{2}{|c|}{$\begin{array}{l}\text { Proportion of } \\
\text { C-14 in shoot }\end{array}$}} \\
\hline & \multirow[b]{2}{*}{$\mathrm{df}$} & \multirow{2}{*}{$\begin{array}{l}\text { Shoot dry } \\
\text { Wt. (g) }\end{array}$} & \multirow{2}{*}{$\begin{array}{l}\text { Root dry } \\
\text { Wt. (g) }\end{array}$} & \multirow{2}{*}{$\begin{array}{l}\text { Total dry } \\
\text { Wt. (g) }\end{array}$} & & & \\
\hline & & & & & & $\mathrm{df}$ & $\mathrm{C}-14$ \\
\hline $\mathrm{HQ} \times \mathrm{INOC}$ & 3 & $0.017 * *$ & 0.018 & $0.044 * *$ & 0.038 & & \\
\hline $\mathrm{HQ} \times \mathrm{C}$ vs $\mathrm{D}$ & 1 & 0.001 & 0.021 & 0.002 & 0.015 & & \\
\hline $\mathrm{HQ} \times \mathrm{D}$ vs $\mathrm{R}$ & 1 & 0.005 & 0.000 & 0.014 & 0.023 & & \\
\hline $\mathrm{HQ} \times \mathrm{D}$ vs $\mathrm{G}$ & 1 & $0.020^{*}$ & 0.029 & $0.057 *$ & 0.023 & & \\
\hline $\mathrm{OL} \times \mathrm{HL} \times \mathrm{INOC}$ & 3 & 0.008 & 0.050 & 0.012 & $0.068^{* *}$ & & \\
\hline $\mathrm{OL} \times \mathrm{HL} \times \mathrm{C}$ vs $\mathrm{D}$ & 1 & 0.005 & $0.108^{*}$ & 0.002 & $0.201 * *$ & & \\
\hline $\mathrm{OL} \times \mathrm{HL} \times \mathrm{D}$ vs $\mathrm{R}$ & 1 & 0.001 & 0.021 & 0.000 & 0.057 & & \\
\hline $\mathrm{OL} \times \mathrm{HL} \times \mathrm{D}$ vs $\mathrm{G}$ & 1 & $0.022 *$ & 0.000 & 0.018 & 0.033 & & \\
\hline $\mathrm{OL} \times \mathrm{HQ} \times \mathrm{INOC}$ & 3 & $0.014 *$ & $0.066^{*}$ & $0.034 *$ & 0.018 & & \\
\hline $\mathrm{OL} \times \mathrm{HQ} \times \mathrm{C}$ vs $\mathrm{D}$ & 1 & 0.005 & $0.121^{*}$ & $0.042 *$ & 0.042 & & \\
\hline $\mathrm{OL} \times \mathrm{HQ} \times \mathrm{D}$ vs $\mathrm{R}$ & 1 & 0.000 & 0.052 & 0.011 & 0.032 & & \\
\hline $\mathrm{OL} \times \mathrm{HQ} \times \mathrm{D}$ vs $\mathrm{G}$ & 1 & $0.033 * *$ & $0.170^{* *}$ & $0.092 * *$ & 0.032 & & \\
\hline Error $b^{d}$ & 152 & 0.005 & 0.019 & 0.011 & 0.020 & $132^{\mathrm{e}}$ & 0.002 \\
\hline
\end{tabular}

${ }^{\text {a }}$ Data were transformed as needed [shoot dry wt. (inverse square root); root dry wt., total dry wt., and shoot/root dry wt. ratio (natural $\log$ ) ]. *, ** indicate significance at 0.05 and 0.01 , respectively.

${ }^{\mathrm{b}}$ Error a used to test Rep, $\mathrm{O}_{3}, \mathrm{O}_{L}, \mathrm{O}_{Q}$ and $\mathrm{O}_{C}$.

${ }^{\mathrm{c}}$ Pre-planned, 1-df contrasts to compare inoculum effects. $\mathrm{C}$ vs $\mathrm{D}=$ noninoculated vs. dual-inoculated; $\mathrm{D}$ vs $\mathrm{R}=$ dual-inoculated vs $R$. leguminosarum only-inoculated; $\mathrm{D}$ vs $\mathrm{G}=$ dual-inoculated vs $G$. margarita only-inoculated.

${ }^{d}$ Error $b$ was used to test all effects in the model not listed in ${ }^{b}$ above. Error b contains sums of squares and associated $\mathrm{df}$ from all higher-order polynomial terms that did not significantly affect any of the biomass response variables and those from Rep $\times$ treatment interactions. The model-building procedure is outlined in Rawlings, 1988, p. 384.

${ }^{\mathrm{e}}$ The procedure described in ${ }^{\mathrm{d}}$ was used to produce the response model for proportion of ${ }^{14} \mathrm{C}$ in shoots. A slightly different model was obtained. $\mathrm{No}_{3} \times \mathrm{HARV} \times \mathrm{INOC}$ interaction effects were significant, so all sums of squares and df for those effects were pooled with the error $b$ term. All other interaction terms for which no df are shown in the table are also included in the error $b$ term.

Table I). Effects of $\mathrm{O}_{3}$ on root and shoot biomass were similar to those shown for total biomass (Figure 1), except for slightly greater suppression of roots than shoots.

Differences attributable to effects of inoculum type on shoot, root, and total biomass increased over time as shown for total biomass (Figure 2) and were especially noticeable at harvests 5 and $6\left(\mathrm{H}_{l} \times\right.$ INOC, $\mathrm{p}<0.01$; Table I). Biomass was usually greatest for plants infected by $R$. leguminosarum only and least for plants infected by G. margarita only. When both symbionts were present, the effects on plant-growth by the mycorrhizal fungus and Rhizobium effectively cancelled, and the plants grew similarly to the noninoculated controls. 


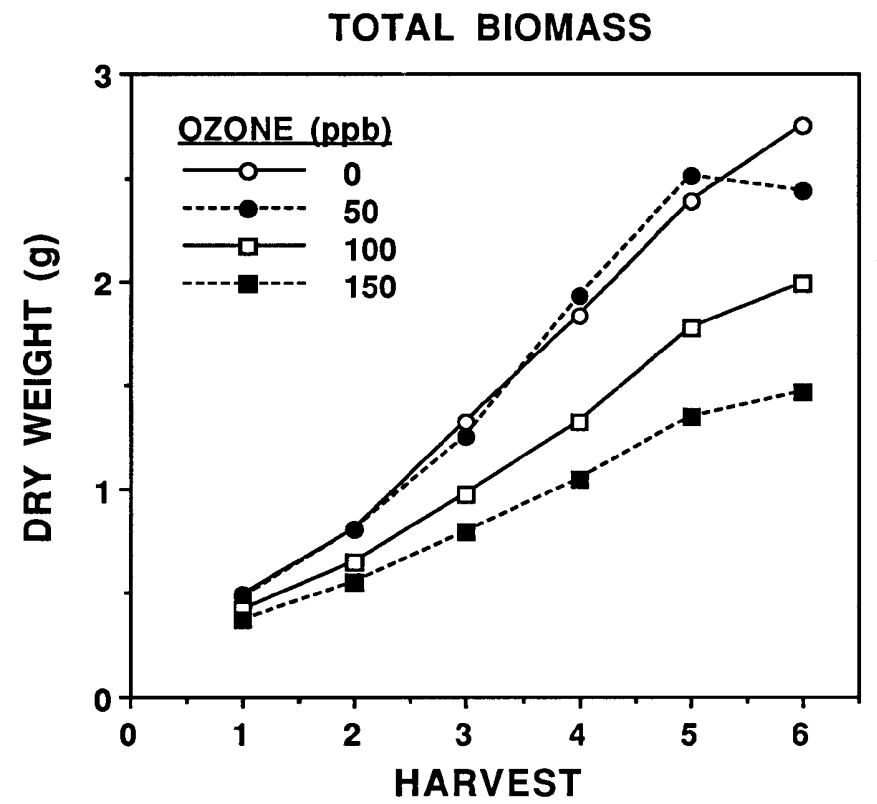

Figure 1. Main effects of $\mathrm{O}_{3}$ on total plant biomass at 2-wk harvest intervals (data averaged across inoculum types).

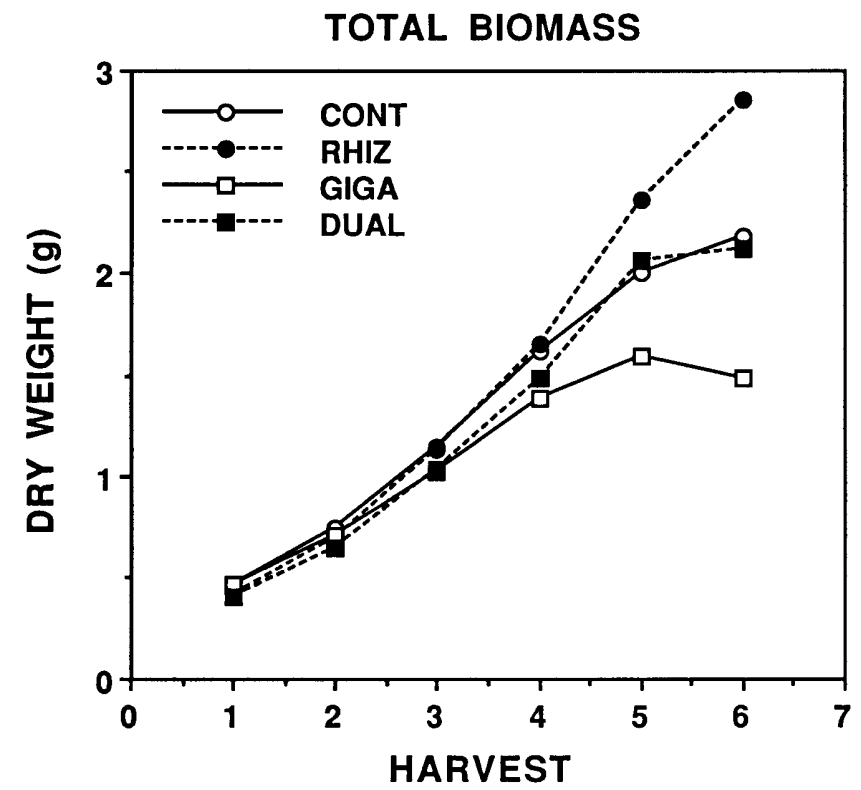

Figure 2. Effects of inocula on total plant biomass at 2-wk harvest intervals. Data averaged across $\mathrm{O}_{3}$ concentrations. Inoculum treatments: noninoculated control (CONT), Rhizobium leguminosarum only (RHIZ), Gigaspora margarita only (GIGA), and both microorganisms (DUAL). 

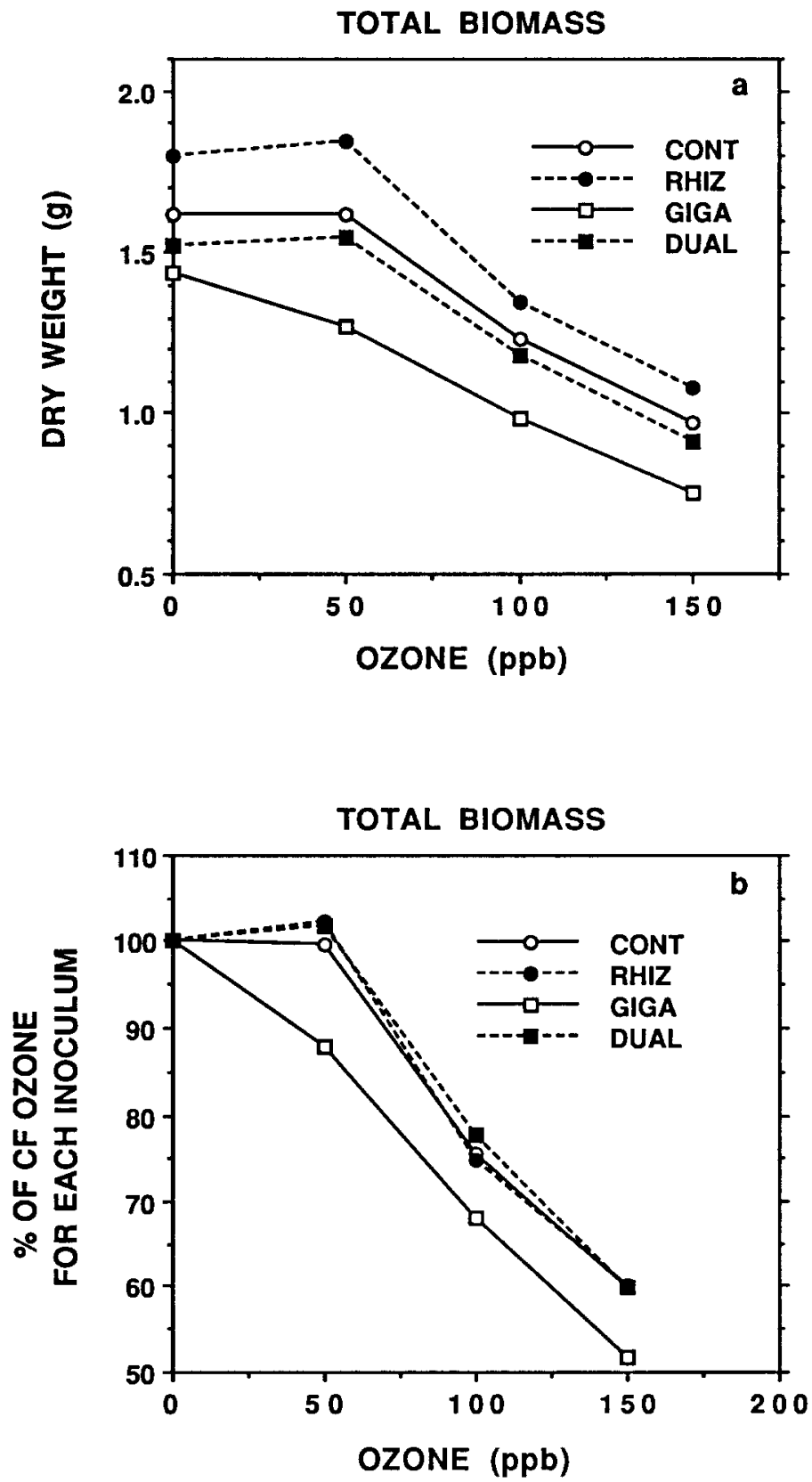

Figure 3. Effects of inocula on response of total biomass to $\mathrm{O}_{3}$. Data averaged across harvests. Data expressed as: (a) dry weight, (b) percentage of CF dry weight for each inoculum type. 
The response of shoot and total biomass to $\mathrm{O}_{3}$ were affected by inoculum type (Figure 3a) $\left(\mathrm{O}_{l} \times\right.$ INOC; shoot dry wt. $\mathrm{p}<0.01$, total dry wt. $\mathrm{p}<0.05$; Table I). Plants inoculated with $R$. leguminosarum had greater biomass, and plants inoculated with $G$. margarita had less biomass across all $\mathrm{O}_{3}$ concentrations than the noninoculated control or dual-inoculated plants. To compare relative response to $\mathrm{O}_{3}$, the total dry weights for plants with different inoculum types were expressed as percentages of those for plants with corresponding inoculum type exposed to $\mathrm{CF}$ (Figure 3b). The relative response of the plants to $\mathrm{O}_{3}$ was similar except for plants inoculated with $G$. margarita, which were most responsive to $\mathrm{O}_{3}$. The $\mathrm{O}_{3} \times$ inoculum interaction was the primary interest in this experiment. The poor growth of the plants inoculated with G. margarita alone, even in the absence of $\mathrm{O}_{3}$ stress, probably reflected the marginal energy status of these plants. Under the conditions of this experiment, the $\mathrm{C}$ sink imposed by the fungus apparently outweighed any beneficial effects, and even the ordinarily mild stress of $50 \mathrm{ppb} \mathrm{O}_{3}$ suppressed growth.

Interpretation of $\mathrm{O}_{3} \times$ inoculum interactive effects on biomass components (Figure 4) is complicated further by changes over time $\left(\mathrm{O}_{l} \times \mathrm{H}_{q} \times \mathrm{INOC}, \mathrm{p}<0.05\right.$; Table I). The 1-df contrasts for $\mathrm{O}_{l} \times \mathrm{H}_{q} \times$ (dual-inoculated vs Gigaspora only) were significant $(\mathrm{P}<0.05)$ for shoot, root, and total dry weight (e.g. Figure $4 d$ vs. 4b). Significance of this interaction may be due in part to the cessation of growth by the $\mathrm{O}_{3}$-treated, $G$. margarita inoculated plants late in the experiment, in contrast to the dual-inoculated plants.

Shoot/Root Ratios. Main effects of $\mathrm{O}_{3}$, inoculum, and harvest date on shoot/root dry weight ratios (S/R) were significant (Table I). Values of S/R were greatest for plants grown in the higher $\mathrm{O}_{3}$ concentrations $\left(\mathrm{O}_{L}, \mathrm{p}<0.05\right)$, especially $150 \mathrm{ppb}$ (Figure 5a). Effects of $\mathrm{O}_{3}$ on $\mathrm{S} / \mathrm{R}$ differed among harvests $\left(\mathrm{O}_{L} \times \mathrm{H}_{L}, \mathrm{p}<0.05\right)$, although the differences were not large. Values of $S / R$ were usually lower for noninoculated and Gigaspora-inoculated compared to dual-inoculated plants (C vs $\mathrm{D}$ and $\mathrm{D}$ vs $\mathrm{G}, \mathrm{p}<0.05$ ) (Figure $5 \mathrm{~b}$ ). No differences were maintained consistently among plants grown in the other infested soils. Ratios were lower at the last three harvests than at the first three harvests regardless of inoculum type $\left(\mathrm{H}_{L}\right.$ and $\mathrm{H}_{W}$, $\mathrm{p}<0.01)$.

The $\mathrm{O}_{3} \times$ inoculum interaction was not significant for $\mathrm{S} / \mathrm{R}$ (Table I); however, the three-way interaction $\left(\mathrm{O}_{l} \times \mathrm{H}_{l} \times\right.$ INOC) was significant $(\mathrm{p}<0.01$; Figure 6$)$. The interaction probably resulted in part from the relatively high $\mathrm{S} / \mathrm{R}$ for the dualinoculated/150 $\mathrm{ppb} \mathrm{O}_{3}$-treated plants at harvests 2, 3, 4, and 5 (Figure 6d). High $\mathrm{S} / \mathrm{R}$ resulted from slow root growth during this period, which probably occurred because of the $\mathrm{C}$ demands of the two microorganisms in combination with the $\mathrm{C}$ limitation imposed by the high $\mathrm{O}_{3}$ stress.

${ }^{14} \mathrm{C}$ Partitioning. The partitioning of recently fixed ${ }^{14} \mathrm{C}$ between shoots and roots was measured to determine how limitation of $\mathrm{C}$ supply due to $\mathrm{O}_{3}$ stress interacted with the likely increased $\mathrm{C}$ demand due to the presence of the symbionts. The proportion of ${ }^{14} \mathrm{C}$ in shoots was affected by $\mathrm{O}_{3}\left(\mathrm{O}_{l}\right.$ and $\mathrm{O}_{q}, \mathrm{p}<0.05$; Table I) and 

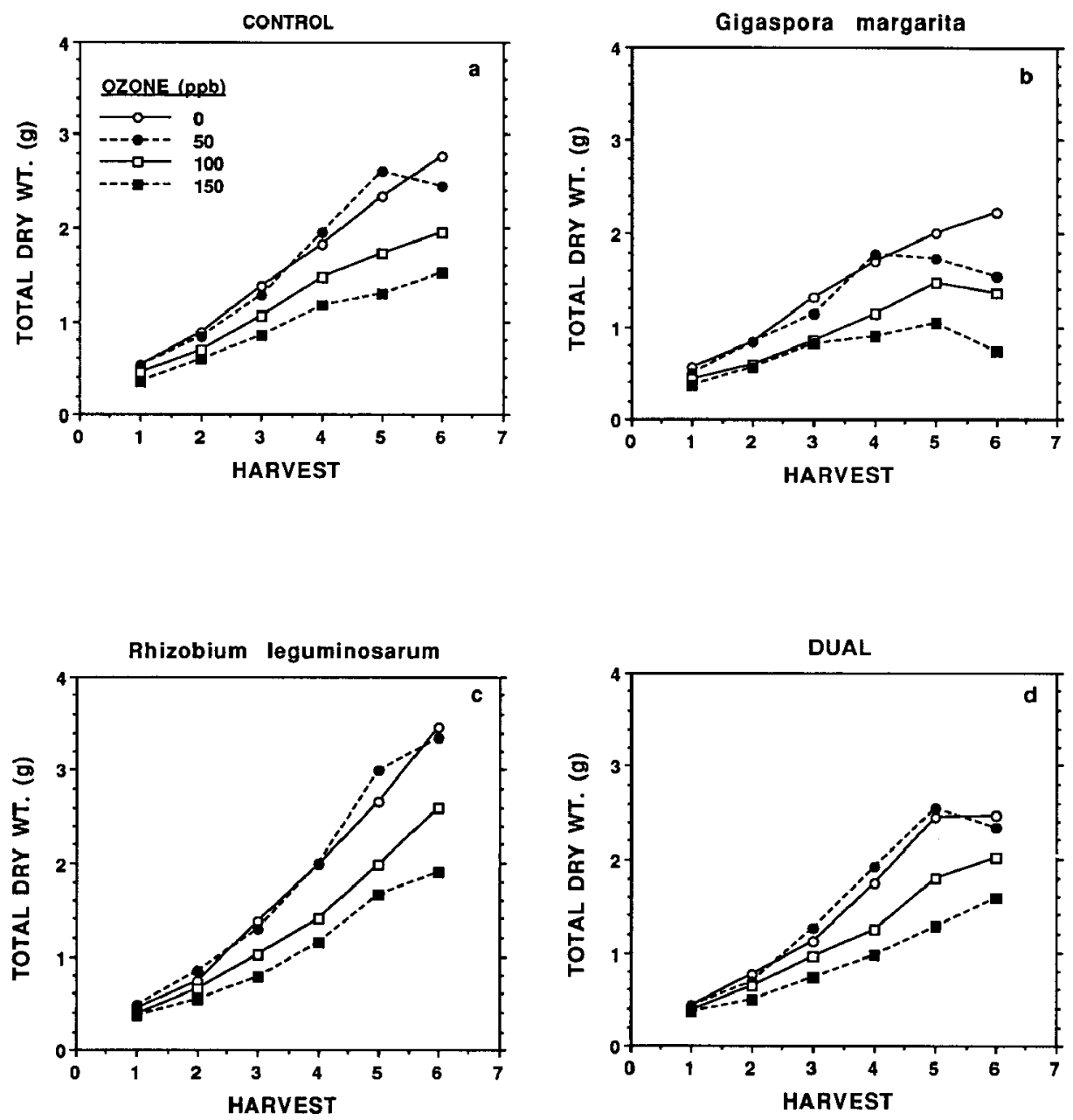

Figure 4. Effects of $\mathrm{O}_{3}$ on total biomass at 2-wk harvest intervals for each inoculum type.

was greatest in plants treated with $150 \mathrm{ppb} \mathrm{O}_{3}$ (Figure 7a and b). The allocation of ${ }^{14} \mathrm{C}$ in response to $\mathrm{O}_{3}$ treatment is generally consistent with observed effects on $\mathrm{S} / \mathrm{R}$ ratios. For example, the greatest retention of ${ }^{14} \mathrm{C}$ in shoots occurred in response to $150 \mathrm{ppb} \mathrm{O}_{3}$, and $\mathrm{S} / \mathrm{R}$ values were greatest for plants exposed to that concentration.

The main effect of inoculum on ${ }^{14} \mathrm{C}$ retention in shoots was nonsignificant, but the microorganisms did affect the $\mathrm{O}_{3}$-induced retention of ${ }^{14} \mathrm{C}$ in shoots (Figure 7a) $\left(\mathrm{O}_{l} \times\right.$ INOC, $\mathrm{p}<0.05$; Table I). The most notable differences were for the CFand $50 \mathrm{ppb}_{3}$-treated plants, among which dual-inoculated plants retained less ${ }^{14} \mathrm{C}$ in shoots than noninoculated control plants $\left[\mathrm{O}_{l} \times\right.$ (noninoculated vs dualinoculated plants), $\mathrm{p}<0.01]$. Plants inoculated with $G$. margarita had less apparent retention of ${ }^{14} \mathrm{C}$ in shoots compared to controls in the $\mathrm{CF} \mathrm{O}_{3}$ treatment, but the pre- 

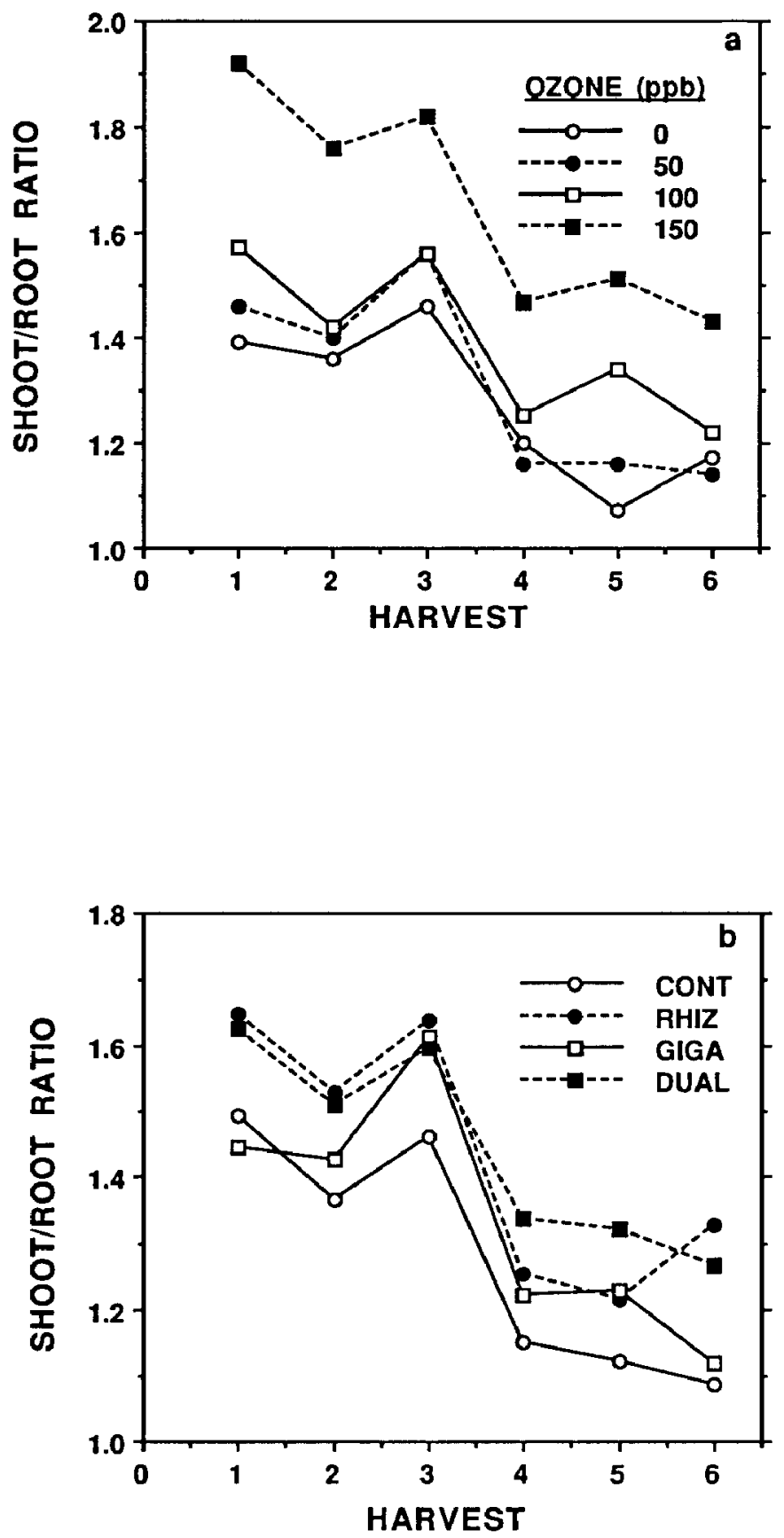

Figure 5. Shoot/root ratios at 2-wk harvest intervals. (a) Effects of $\mathrm{O}_{3}$ for data averaged across inoculum types. (b) Effects of inoculum type for data averaged across $\mathrm{O}_{3}$ concentrations. 

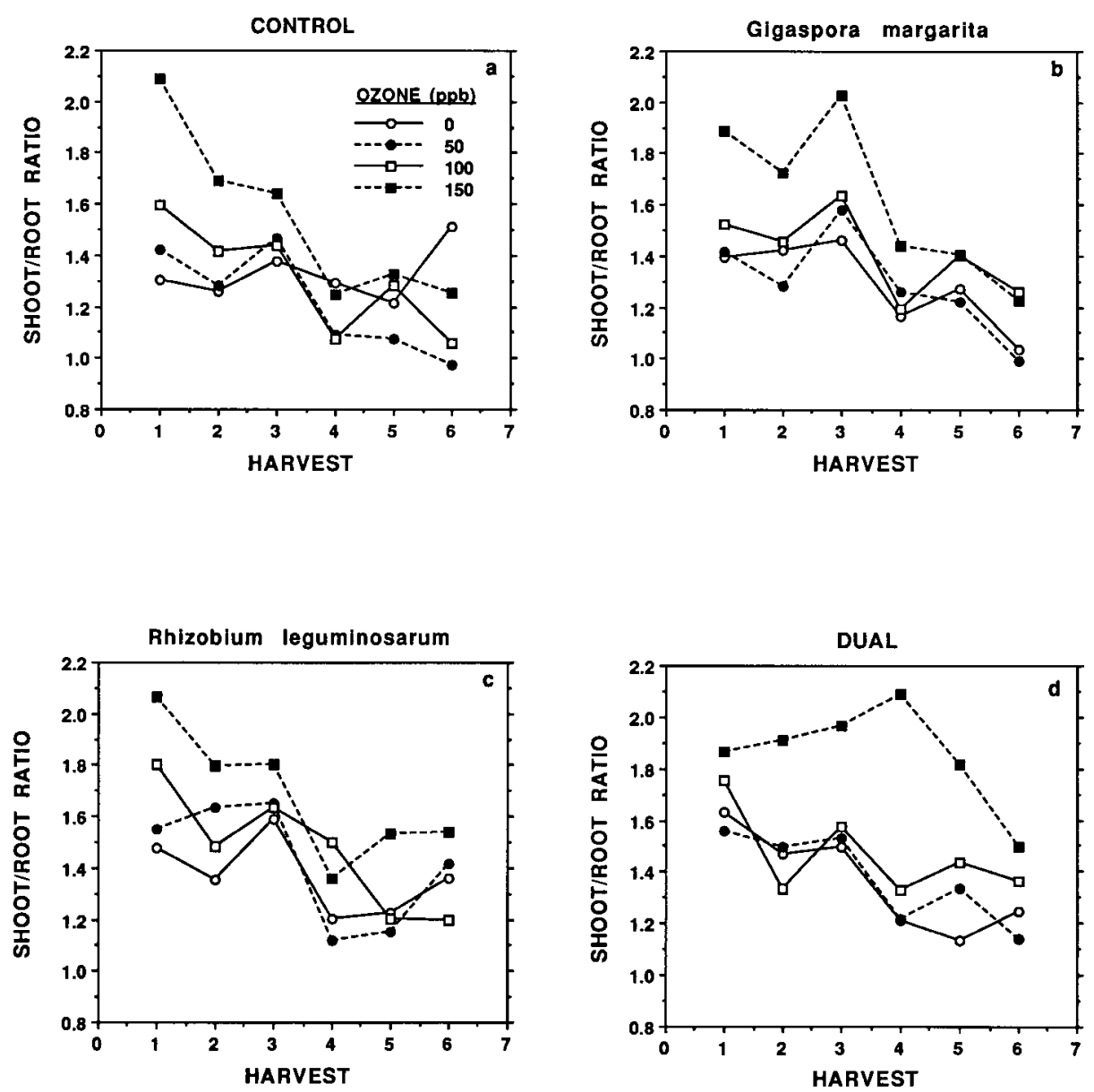

Figure 6. Effects of $\mathrm{O}_{3}$ on shoot/root ratios at 2-wk harvest intervals for each inoculum type.

planned 1-df contrasts did not include a comparison of the G. margarita-treated and noninoculated control treatments. Apparently, under conditions of low $\mathrm{O}_{3}$ stress, roots received an increased proportion of recently-fixed $\mathrm{C}$ when both soil microorganisms were present. $\mathrm{As}_{3}$ stress increased, this difference did not persist, probably because of reduced $\mathrm{C}$ availability due to suppression of photosynthesis by $\mathrm{O}_{3}$ and increased demand for $\mathrm{C}$ by shoots for repair of injury. Under conditions of stress and limited $\mathrm{C}$ availability, shoots usually take priority over roots for receiving photosynthate (e.g. studies reviewed by Cooley and Manning, 1987).

Effects of $\mathrm{O}_{3}$ on proportion of ${ }^{14} \mathrm{C}$ in shoots (Figure $7 \mathrm{~b}$ ) changed over time $\left(\mathrm{O}_{l} \times \mathrm{H}_{f}, \mathrm{p}<0.05\right.$; Table I). For example, the proportion of ${ }^{14} \mathrm{C}$ in shoots was similar among plants exposed to 0,50 , or $100 \mathrm{ppb} \mathrm{O}_{3}$ by harvests 2 and 3, but the proportions diverged at the later harvests. The proportion of ${ }^{14} \mathrm{C}$ in shoots was consistently highest across all harvest dates for plants exposed to $150 \mathrm{ppb} \mathrm{O}_{3}$. 

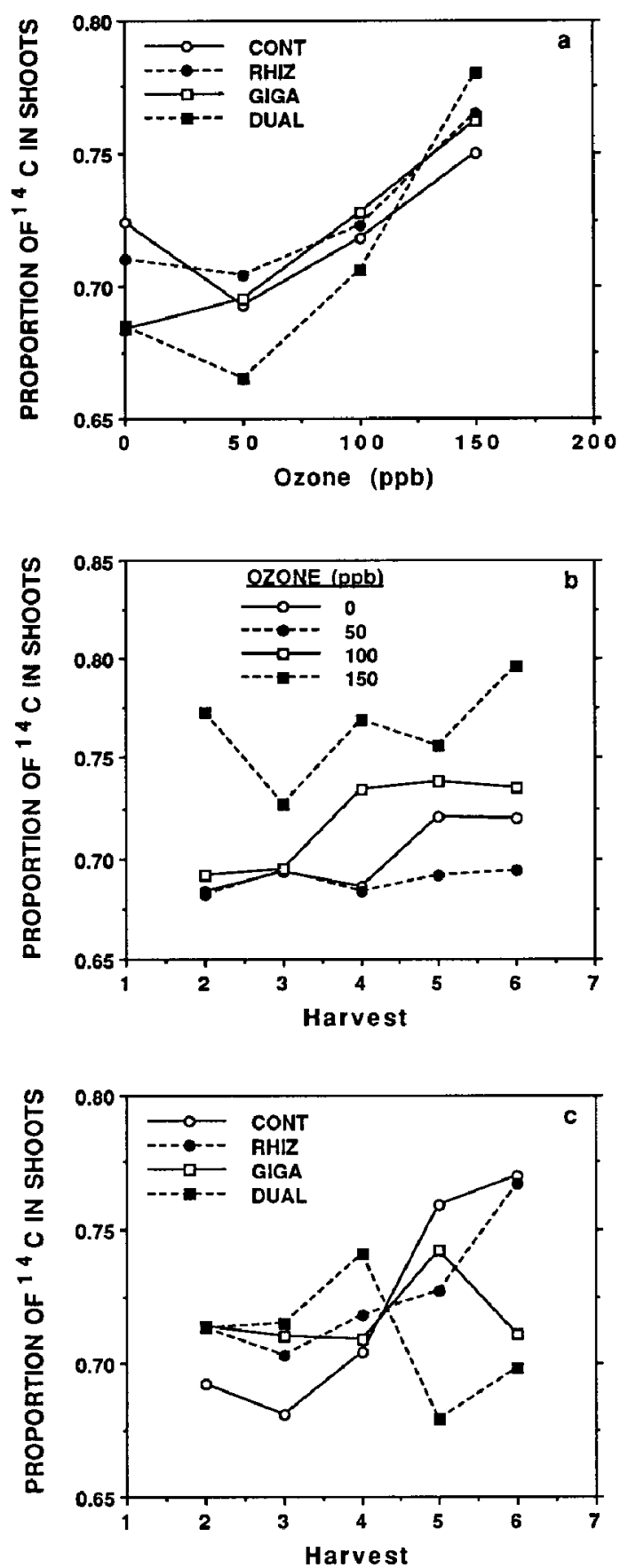

Figure 7. Proportion of C-14 in shoots. (a) Effects of $\mathrm{O}_{3}$ for each inoculum type; data averaged across harvests. (b) Effects of $\mathrm{O}_{3}$ concentration over time (harvest dates); data averaged across inoculum types. (c) Effects of inoculum types over time (harvest dates); data averaged across $\mathrm{O}_{3}$ concentrations. 
The proportion of ${ }^{14} \mathrm{C}$ in shoots was affected by harvest date (Figure $\left.7 \mathrm{c}\right)\left(\mathrm{H}_{l}\right.$, $\mathrm{p}<0.01$ : Table I), but this relationship varied among plants that were inoculated differently $\left(\mathrm{H}_{l} \times\right.$ INOC, $\left.\mathrm{p}<0.01\right)$. The proportion of ${ }^{14} \mathrm{C}$ retained in shoots was less in noninoculated control plants than in inoculated plants at harvest 2 and 3. At harvests 5 and 6 this reversed, and the dual-inoculated plants had the lowest proportion of ${ }^{14} \mathrm{C}$ in shoots $\left[\mathrm{H}_{l} \times\right.$ (noninoculated vs dual-inoculated plants) and $\mathrm{H}_{l}$ $\times$ (dual-inoculated vs. Rhizobium-only inoculated plants), $\mathrm{p}<0.01]$. This shift after harvest 4 probably reflects increased $C$ demand by roots due to increased microbial activity in the dual-inoculated plants during the late stages of the experiment.

\section{Conclusions}

Most studies of the impact of $\mathrm{O}_{3}$ on plant growth, development, and carbon allocation have not considered the potential role of symbiotic microorganisms as factors that can mediate plant responses. Some influences of root symbionts on plant response to $\mathrm{O}_{3}$ have been reported previously (e.g. McCool and Menge, 1983 and 1984; Shafer and Schoeneberger, 1991a), but our study shows that these influences vary with the combination of symbionts present, among concentrations of $\mathrm{O}_{3}$, and over time. Furthermore, the combination of biomass, shoot/root ratio, and ${ }^{14} \mathrm{C}$ label data demonstrate the role of carbon allocation in explaining these effects. These findings have important implications with respect to the interpretation of studies of plant response to $\mathrm{O}_{3}$ and the extrapolation of results to plants grown under different conditions. Studies of plant response to $\mathrm{O}_{3}$ are often done in artificial or disinfested rooting media that precludes association with root symbionts. The resulting over-simplification of the plant-soil system can lead to an incomplete assessment of responses of carbon allocation and plant growth to $\mathrm{O}_{3}$. Our results illustrate the value of including appropriate microbial inocula in studies of plant responses to $\mathrm{O}_{3}$.

\section{Acknowledgments}

Special thanks are due to Joanne Shyr for plant maintenance, analysis, and data collection. We thank Paula Bell, Tommy Gray, Jeff Barton, and Gwen Palmer for assistance during plant harvests.

\section{References}

Alscher, R. G. and Wellburn, A. R. (eds.): 1994, Plant Responses to the Gaseous Environment, Chapman and Hall, London, U.K.

Bethlenfalvay, G. J., Brown, M. S. and Pakovsky, R. S.: 1982, Phytopathology 72, 889-893.

Box, G. E. P. and Cox, D. R.: 1964, J. R. Stat. Soc. Ser. B 26, 211-243.

Brewer, P. F. and Heagle, A. S.: 1983, Phytopathology 73, 1035-1040. 
Cooley, D. R. and Manning, W. J.: 1987, Environ. Pollut. 47, 95-113.

Flagler, R. B., Patterson, R. P., Heagle, A. S. and Heck, W. W.: 1987, Crop Sci. 27, 1177-1184.

Heck, W. W., Philbeck, R. B. and Dunning, J. A.: 1978, Agricultural Research Service, Series No. ARS-S-181, pp. 32.

McCool, P. M. and Menge, J. A.: 1983, New Phytol. 94, 241-247.

McCool, P. M. and Menge, J. A.: 1984, Soil Biol. Biochem. 16, 425-427.

Miller, J. E.: 1988, in Heck, W. W., Taylor, O. C. and Tingey, D. T. (eds.), Assessment of Crop Loss From Air Pollutants, Elsevier Science Publishers, London, U.K., pp. 287-314.

Modjo, H. S. and Hendrix, J. W.: 1986, Phytopathology 76, 688-691.

Montes, R. A., Blum, U., Heagle, A. and Volk, R. J.: 1983, Can. J. Bot. 61, 2159-2168.

Rawlings, J. O.: 1988, Applied Regression Analysis: A Research Tool, Wadsworth and Brooks, Pacific Grove, CA.

Safir, G. R.: 1994, in Pfleger, F. L. and Linderman, R. G. (eds.), Mycorrhizae and Plant Health, APS Press, St. Paul, MN, pp. 239-259.

SAS Institute, Inc.: 1988, SAS/AF User's Guide: Version 6.03 Edition, SAS Institute, Inc., Cary, NC.

Shafer, S. R. and Schoeneberger, M. M.: 1991a, Environ. Pollut. 73, 163-177.

Shafer, S. R. and Schoeneberger, M. M.: 1991b, in Keister, D. L. and Creagan, P. B. (eds.), The Rhizosphere and Plant Growth, Kluwer Academic Publishers, Dordrecht, the Netherlands, pp. 377.

Tingey, D. T. and Blum, U.: 1973, J. Environ. Qual. 2: 341-342.

Vincent, J. M.: 1970, A Manual for the Practical Study of Root-Nodule Bacteria, International Biological Program Handbook 15. Blackwell Scientific Publication, Ltd., Oxford. p. 164. 